\title{
SOCIOEMOCIONALNI KONTEKST PRIVRŽENOSTI KUĆNIM LJUBIMCIMA
}

\author{
Jelena Ombla \\ Odjel za psihologiju, Sveučilište u Zadru \\ Obala kralja Petra Krešimira IV br. 2, 23000 Zadar \\ jlevac@unizd.hr \\ Zvjezdan Penezić \\ Odjel za psihologiju, Sveučilište u Zadru \\ Obala kralja Petra Krešimira IV br. 2, 23000 Zadar \\ zvjezdan@unizd.hr \\ Marina Vidaković \\ Odjel za psihologiju, Sveučilište u Zadru \\ Obala kralja Petra Krešimira IV br. 2, 23000 Zadar \\ mjurkin@unizd.hr
}

\begin{abstract}
Sažetak
Kućni ljubimci globalno su raširen fenomen i predstavljaju neizostavni dio svakodnevice kod više od polovine stanovništva. Svrha odnosa vlasnik-kućni ljubimac nije eksplicitno definirana, kao što ni sama uloga vlasnika kućnih ljubimaca nije zahtijevana niti socijalno očekivana od strane okoline, što čini ovo područje znanstveno intrigantnim. Istraživanja pokazuju kako ljudi značajno vrednuju svoje kućne ljubimce, poglavito kada je riječ o psima, pridajući im ulogu članova obitelji te stvarajući s njima jedan bliski afektivni odnos. Skrbništvo nad psima kao vrsti kućnih ljubimaca predstavlja funkcionalan i koristan resurs za čovjeka, gotovo poput zasebne socijalne zalihe. Proučavanja karakteristika odnosa koji ljudi uspostavljaju prema svojim kućni ljubimcima, u posljednje vrijeme napravila su svojevrstan zaokret fokusirajući se na eksploraciju elemenata privrženosti u ovom odnosu. Odrednice kvalitete bliskih odnosa, čini se, igraju ulogu u razvoju privrženosti u odnosu vlasnik-kućni ljubimac, dok mehanizmi djelovanja na čovjekovu dobrobit iziskuju daljnja istraživanja. Sve u svemu, čini se kako bi neke osobne karakteristike vlasnika ljubimaca, od socioemocionalnih aspekata funkcioniranja pa do stavova i vrijednosnih orijentacija, mogle biti osobito bitne pri definiranju kvalitete, a potom i ishodnih implikacija ovog odnosa.
\end{abstract}

Ključne riječi: kućni ljubimci, socioemocionalni kontekst, privrženost 


\section{UVOD}

Posjedovanje kućnih ljubimaca nerijetko se u literaturi karakterizira kao „evolucijski nelogičan odnos zavisnosti“" (npr. Baston, 2009) koji nema eksplicitno definiranu svrhu, dok je u modernom svijetu osobito teško elaborirati objektivne razloge uzimanja kućnih ljubimaca pod skrb. Nametanje dodatnih fizičkih, materijalnih, vremenski okupirajućih i emocionalno iscrpljujućih zahtjeva čovjekovoj svakodnevici čini se nepotrebnim i racionalno neshvatljivim. Tim više što uloga vlasnika kućnog ljubimca nije ni na koji način nametnuta niti očekivana od okoline (kao što je to, recimo, roditeljstvo). Upravo iz tih razloga, istraživanja ovog aspekta čovjekova svakodnevnog života znanstveni su izazov.

Među prvim životinjskim vrstama s kojima je čovjek počeo dijeliti svoj život bio je pas, što potvrđuju nalazi stari i nekoliko tisuća godina (Gunter, 1999), a obrambena i zaštitnička uloga tih prvih pripitomljenih vukova pronašla je svoje mjesto u čovjekovoj svakodnevnoj borbi za preživljavanjem. Dakle, vezivanje čovjeka konkretno za psa, doista je bio jedan od ranijih oblika adaptivnog ponašanja. S druge strane, odnos koji je čovjek u prošlosti začeo kako bi pospješio svoje izglede za preživljavanje u (tada) prilično nepredvidivoj okolini, danas nedvojbeno gubi značajke instrumentalne podrške i čini se da poprima obilježja obostrano afektivnog odnosa. Sife (2005) navodi kako je s evolucijom civilizacije evoluirala i uloga kućnih ljubimaca. Ádám Miklósi (2007), voditelj budimpeštanskog sveučilišnog Laboratorija za proučavanje obiteljskih pasa, pretpostavlja kako se dogodila velika evolucijska promjena da bi divlja životinja poput vuka postala pas. Nadalje, psi su morali otkriti kako živjeti u novom staništu, ljudskom domu, i shvatiti čovjekov svijet. Isti autor navodi kako psi bolje razumiju i rabe naše društvene signale nego primati s kojima ipak dijelimo dobar dio genetskog naslijeđa. Danas se smatra kako su se kroz proces domestikacije (koji je započeo prije 10000 godina) kod pasa izolirale specifične anatomske i bihevioralne crte kao i dispozicija da uspostave određen emocionalni odnos s ljudima (Millott, 1994). Psi su najomiljenija i najpopularnija vrsta kućnih ljubimaca (Hart, 1995). Rezultati istraživanja sustavno potvrđuju kako se čovjek emocionalno najsnažnije veže upravo za psa kao vrstu kućnog ljubimca (npr. Siegel, 1990; Johnson, Garrity i Stallones, 1992).

Potencijalnu znanstvenu vrijednost istraživanja psiholoških (a i drugih) aspekata posjedovanja kućnih ljubimaca ilustrira jednostavna činjenica - posjedovanje kućnih ljubimaca je globalni fenomen. Tako je, recimo, u 2011. godini u 39\% kućanstava u SAD-u registriran najmanje jedan pas kao ljubimac (www.humanesociety.org), 43\% kućanstava Ujedinjenog Kraljevstva ima kućnog ljubimca (www. dogsnews.co.uk), dok je zemlja s najvećom incidencijom kućanstava u kojima je registriran ljubimac Australija sa 63\% (www.petnet.com.au). U istraživanju koje je 2009. godine provela jedna anketarska kompanija u ime Udruge za zaštitu životinjaFutura, na uzorku građana $\mathrm{RH}(\mathrm{N}=1000)$ reprezentativnom prema regijama, spolu $\mathrm{i}$ dobi (18+), dobiveno je da otprilike polovina (51\%) ima neku životinju kao kućnog 
ljubimca. Recentni podatak iz 2016. godine vezan uz incidenciju posjedovanja kućnih ljubimaca u našoj zemlji dolazi iz online istraživanja GfK-Centra za istraživanje tržišta, prema kojem čak $61 \%$ hrvatskog stanovništva ima kućne ljubimce, od čega njih $41 \%$ za kućnog ljubimca ima psa (www.askgfk.hr). U sklopu šire studije koja je bila usmjerena na provjeru karakteristika odnosa vlasnik-kućni ljubimac na hrvatskom uzorku od 286 vlasnika pasa, Ombla (2014) izdvaja podatak prema kojem $77 \%$ sudionika svog ljubimca smatra članom obitelji. Dosadašnje studije koje su se bavile percepcijom kućnih ljubimaca u kontekstu obitelji navode slične rezultate (npr. Cain, 1985, Albert i Bulcroft, 1988, Allen, 2003).

Odnos između vlasnika i kućnih ljubimaca fizički se smješta u kontekst bliske, prvenstveno obiteljske interpersonalne domene, stoga nije začuđujuće da su istraživanja u ovom području teorijsko uporište uglavnom pronalazila u konceptu privrženosti. Shaver i Mikulincer (2010) pozicioniraju teoriju privrženosti kao ključnu polazišnu osnovu istraživanja interpersonalnih odnosa, uz preporuku daljnjeg razvoja teorijski utemeljenih istraživačkih instrumenta te obuhvaćanje različitih aspekata privrženih odnosa. Naime, jedan od nedostataka klasične teorije privrženosti, tiče se implicitnih pretpostavki koje su proizašle iz ove teorije, poput one da je privrženost nešto što se u određenoj interpersonalnoj domeni očituje po principu ili-ili (ili određen tip veze jest privrženost, ili nije) (Cassidy, 1999). Tako se, recimo, u literaturi o ranim vezama privrženosti tipično navodilo kako su sva djeca privržena svojim skrbnicima, dok se smatralo kako individualne razlike u privrženosti odražavaju razlike u kvaliteti veze a ne razlike u stupnju privrženosti ili (ne)postojanje privrženosti same po sebi. Također, u kontekstu romantičnih odnosa, a priori se pretpostavljalo kako su svi partnerski odnosi (izuzevši one kratkotrajne) zapravo odnosi privrženosti a da su se takve pretpostavke zapravo nedovoljno provjeravale. Upravo njih su se teoretičari (kao i istraživači donedavno) tako strogo držali da su za posljedicu imale nerazjašnjavanje postupaka kojim bi se jasno razlikovale veze privrženosti od onih veza koje to nisu. Prema upravo navedenom, Fraley i Shaver (2000) upozoravaju kako je kod svakog ispitivanog bliskog odnosa nužno utvrditi ulogu koju privrženost igra u konkretnom odnosu, na teorijski opravdan način, odnosno koristeći tehnike koje operacionaliziraju ključne koncepte i postavke teorije privrženosti. Prema spomenutim autorima opravdano je vjerovati kako su procesi u podlozi privrženosti odraz ne samo stilova privrženosti, već i stupnja u kojem neki odnos ispunjava funkcije karakteristične za privrženost (tzv. realizirana privrženost), uz uvjet bliske emocionalne povezanosti. Ovaj početni korak komplicira postojanje različitih teorijskih i empirijskih konceptualizacija privrženosti (Mikulincer i Shaver, 2007), a prema tome i aktualni problemi mjerenja, koji su, kako je i ranije rečeno, posebice naglašeni kada je riječ o odnosu s kućnim ljubimcima.

U ovom radu pružen je trenutačni pregled recentnije empirijske literature kojoj je dodirna točka upravo tematika psihosocijalnih aspekata odnosa koji se formira između ljudi i njihovih kućnih ljubimaca. Također, pokušat će se sumirati zaključci prikazanih studija uz kritičku sugestiju smjera budućih istraživanja u ovom područ- 
ju. Tematika vezana uz operacionalizaciju i konceptualizaciju pojma privrženosti prema kućnom ljubimcu obrađena je u prvom dijelu rada, dok je relevantnost kvalitete socioemocionalnog konteksta pojedinca kao faktora važnog za razvoj bliskosti prema kućnom ljubimcu razmatrana u drugom dijelu teksta.

\section{PRIVRŽENOST U ODNOSU VLASNIK-KUĆNI LJUBIMAC}

Istraživanja sustavno pokazuju kako se ponašanje ljudi prema njihovim kućnim ljubimcima, psima, može smatrati obrascem roditeljskog ponašanja usmjerenog prema jedinkama druge vrste. Vlasnici tretiraju svoje pse poput djece igrajući se s njima (Smith, 1983; Prato-Previde, Fallani i Valsecchi, 2006), pričajući s njima koristeći pritom tzv. majčinski govor (Mitchell, 2001) mazeći ih (Serpell, 1996), tražeći i zadržavajući fizički kontakt s njima (Robinson, 1992; Prato-Previde i sur., 2006 ) te povrh svega brinu o zadovoljavanju njihovih životnih potreba (Baston, 2009). Nadalje, izgleda kako u nekim slučajevima kućni ljubimci zamjenjuju manjak veza privrženosti s ljudima (npr. Garrity, Stallones, Marx i Johnson, 1989; Siegel, Angulo, Detels, Wesch i Mullen, 1999; Rew, 2000; Krause-Parello, 2008), dok u drugima proširuju raspon veza i socijalnih kontakata koji doprinose općem životnom zadovoljstvu te pružaju osjećaj ugode i potpore $u$ težim trenucima (npr. Albert i Bulcroft, 1988; Beck i Katcher, 2003; Bonas, McNicholas i Collins, 2000; Philips Cohen, 2002). Tome u prilog ide podatak da separacija, prijetnja separacijom ili trajni gubitak ljubimca mogu dovesti do pojave separacijske anksioznosti, tuge i žalovanja budući da gubitak voljenog ljubimca ujedno znači i gubitak jednog bliskog afektivnog odnosa (Cowles, 1985; Archer i Winchester, 1994; Sable, 1995).

Za sada se čini sigurnim da odnos vlasnika prema kućnim ljubimcima, poglavito kada je riječ o psima, poprima elemente jednog brižnog (afektivnog) odnosa. Kako je već prije rečeno, pregledom literature u ovom području uočava se gotovo uniformna tendencija istraživača koji se mahom priklanjaju teoriji privrženosti kao polazišnom teorijskom okviru kada je riječ o pojašnjavanju karakteristika tog odnosa. Teorija privrženosti (Bowlby, 1969) primarno se razvila kako bi pojasnila emocionalni odnos majke (odnosno skrbnika) i djeteta, međutim danas se smatra obećavajućim teorijskim okvirom kada je riječ o ispitivanjima bliskih odnosa u odrasloj dobi. Detaljniji uvid u metodologiju većine istraživanja privrženosti kućnim ljubimcima, svakom upućenijem poznavatelju koncepata teorije privrženosti, posve će evidentno otkriti nepotpunu korespondentnost s referiranom teorijom. Crawford, Worsham i Swinehart (2006) upozoravaju kako primjena termina "privrženost" u dosadašnjim studijama odnosa vlasnik-kućni ljubimac tek možda nekim dijelom odgovara tradicionalnoj teoriji privrženosti, međutim još uvijek je daleko od toga da joj odgovara u onoj mjeri koja bi dopustila opravdano korištenje tog termina. Naime, većinski dio studija barata instrumentima za koje se navodi da mjere privrženost ljubimcu iako ustvari zahvaćaju koncept afektivne vezanosti (za 
ljubimca) koji kao takav zapravo pruža informaciju o stupnju emocionalne bliskosti u odnosu (npr. Albert i Bulcroft, 1988; Johnson i sur., 1992; Crawford i sur., 2006). Privrženost uključuje afektivnu povezanost, u smislu želje za blizinom i pozitivnog raspoloženja u kontaktu s bliskom nam figurom te osjećaje neugode pri razdvajanju, ali i specifičnu percepciju odnosa kao sigurnosne utvrde koja nas jača, ohrabruje u vlastitim inicijativama te općenito podupire naš razvoj. Dakle, nužno je razlučiti sljedeće: svi odnosi privrženosti ujedno jesu i afektivne veze, dok obrnuto nužno ne vrijedi (Bell i Richard, 2000). Kurdek $(2008,2009)$ je jedan od autora koji se u svojim istraživanjima detaljnije posvetio pitanjima operacionalizacije aspekata privrženosti u kontekstu odnosa vlasnik-kućni ljubimac. U studiji iz 2008., kod studenata vlasnika pasa ( $\mathrm{N}=923)$ između ostalog ispitivao je i osnovne aspekte privrženosti najbližim osobama i ljubimcu (pas). Kod otprilike petine uzorka psi su zauzimali neko od gornja dva mjesta u hijerarhiji figura privrženosti, što znači da su procijenjeni prvom ili drugom najbližom figurom prema kojoj iskazuju privržena ponašanja. Dimenzije privrženosti u bliskim vezama, Izbjegavanje i Anksioznost, nisu bile povezane s razinom privrženosti ljubimcu. Detaljniju ulogu privrženosti, u smislu realizacije privrženog ponašanja prema ljubimcu pod stresnim okolnostima, isti je autor ispitivao u studiji gdje je kao uzorak koristio skupinu od 925 odraslih vlasnika pasa (Kurdek, 2009). Radilo se o on-line anketi koju su dobrovoljno popunili vlasnici pasa koji su prethodno vidjeli oglas o provođenju istraživanja objavljen u najtiražnijim lokalnim novinama. Oglas je sadržavao podatke o ciljevima istraživanja kao i poveznicu (internetsku adresu) na kojoj se moglo pristupiti anketi. Osnovni cilj ove studije bio je ispitati stupanj i uvjete pod kojima su vlasnici pasa skloni u stresnim trenucima realizirati utješnu funkciju bliskog odnosa u relaciji s ljubimcem, kada se ista uspoređuje s ostalim bliskim odnosima. Rezultati su pokazali da su vlasnici bili spremniji osloniti se na svog ljubimca kao sigurno utočište kada su pod stresom nego na majku, oca, brata, sestru, najboljeg prijatelja i vlastito dijete, no ipak kao primarni oslonac pod stresnim okolnostima navode svog romantičnog partnera.

Detaljniji pregled studija koje su različitim operacionalizacijama privrženosti (izvan aspekta emocionalne bliskosti) pokušale utvrditi prirodu odnosa koji se formira između ljudi i njihovih kućnih ljubimaca (pasa) može se vidjeti kod Ombla (2012). Trenutačno dostupan pregled strane empirijske literature u ovom području sugerira kako u posljednje vrijeme nije bilo značajnijih pokušaja provjere aspekata privrženosti u odnosu vlasnik-kućni ljubimac. Kod nas je Ombla (2014), u sklopu većeg istraživanja, provjeravala i osnovna obilježja spomenutog odnosa u kontekstu privrženosti kod 286 vlasnika pasa. Potvrđen je u najmanju ruku status bliskog odnosa kao onog koji se formira između vlasnika i njihovih kućnih ljubimaca, koji se prema više pokazatelja smješta najbliže domeni obiteljskih odnosa. Procjene funkcija privrženih ponašanja, kao indikatora realizacije privrženosti, značajno su se razlikovale za partnere, članove obitelji i prijatelje u usporedbi s procjenama danim za ljubimca. Ipak vlasnici pasa procjenjivali su kako separacijska anksioznost koju osjećaju u trenucima razdvojenosti od svog ljubimca, te osjećaj utjehe i sigurnosti 
koji pronalaze u tom odnosu varira oko središnjih vrijednosti mogućeg raspona odgovora. Ako se uzme u obzir činjenica da je privrženost emocionalno naintimniji odnos koji čovjek razvija, onda se ovakvi rezultati dobiveni za pse kao figuru privrženosti mogu smatrati vrlo značajnim. Tim više što psi kao kućni ljubimci imaju evidentna ograničenja glede kognitivnih, verbalnih te ponašajnih resursa a koji bi mogli biti značajni faktori u procesu reduciranja stresa kod drugog člana dijade (preduvjeti za realizaciju funkcije sigurnog utočišta). U istraživanju se indikativnom pokazala i uloga radnih modela privrženosti koji značajno uvjetuju stupanj manifestacije karakteristika privrženog ponašanja i u odnosu sa psom.

Teorijski utemeljena provjera karakteristika odnosa vlasnik-kućni ljubimac, sada je jasno, trebala bi se bazirati na utvrđivanju zastupljenosti osnovnih koncepata privrženosti u ovom konkretnom odnosu. Pomak u području je evidentan, što se vidi pregledom recentnije strane, ali i domaće empirijske literature (Kurdek, 2008, 2009; Beck i Madresh, 2008; Ombla 2014). Tek istraživački nacrti s više instrumenata privrženosti, odabranih temeljem njihove teorijske relevantnosti, a s ciljem obuhvaćanja što širih aspekata kvalitete i indikatora realizacije privrženog ponašanja mogu pružiti odgovor o utemeljenosti kvalificiranja odnosa vlasnik-kućni ljubimac kao odnosa privrženosti.

Druga relevantna istraživačka tema kada je riječ o odnosu između ljudi i njihovih kućnih ljubimaca, fokusira se na kontekst interpersonalne okoline i bliskih odnosa u odrasloj dobi kao socijalni milje u koji se odnos s ljubimcem integrira. Čini se kako bi se kvaliteta bliskih interpersonalnih odnosa među značajnim drugima trebala promatrati kao svojevrsna referenična točka u odnosu na koju valja interpretirati odnos vlasnik - kućni ljubimac. Osnovno pitanje ovdje jest definiranje socijalne funkcije kućnih ljubimaca kao i socioemocionalnih karakteristika ljudi koji se intenzivnije, ili manje intenzivno emocionalno vežu za svoje prijatelje među životinjama.

\section{SOCIOEMOCIONALNI KONTEKST PRIVRŽENOSTI LJUBIMCU}

Unatoč većem broju istraživanja čiji su rezultati išli u prilog „pozitivnom efektu ljubimca“", i u ovom području ima kontradiktornih rezultata (npr. Brown i Katcher, 2001; Parslow, Jorm, Christensen, Rodgers i Jacomb, 2005) kao i onih koji upućuju na nekakve specifične relacije (niz istraživanja upućuje na posebnu važnost koju ljubimci imaju kod vulnerabilnih skupina: npr. Albert i Bulcroft, 1988; Garrity i sur., 1989; Johnson i sur., 1992; Siegel i sur., 1999; Allen, Shykoff i Izzo, 2001; Turner, 2005; Krause-Parello, 2008; Stanley, Conwell, Bowen i Van Orden, 2014). Spomenuti nalazi, sve u svemu, upućuju na mogućnost da društvo ljubimca doprinosi dobrobiti upravo kod onih ljudi koji su emocionalno osjetljiviji, čije emocionalne potrebe nisu adekvatno zadovoljene i/ili onih koji prolaze kroz teža razdoblja u svojim životima. Dakle, pri ispitivanjima korelata privrženosti ljubimcima svakako 
bi valjalo uzeti u obzir i širu socioemocionalnu situaciju osobe. Pritom subjektivni doživljaj socijalnih okolnosti može biti osobito informativan. Čini se da bi doživljaj usamljenosti $u$ interpersonalnim odnosima mogao predstavljati relevantnu varijablu. Usamljenost se često u literaturi karakterizira kao pojam suprotan osjećaju pripadanja i zajedništva s drugima (Lacković-Grgin, 2008). Brojne definicije usamljenosti nastale su s obzirom na različita teoretska shvaćanja. Najsažetijim pregledom shvaćanja usamljenosti smatra se onaj Westa i suradnika (1986, prema LackovićGrgin, 2008), koji navodi kako se usamljenost tipično karakterizira kao posljedica (kvalitativnih) deficita u socijalnim odnosima, te kao subjektivno, bolno i neugodno iskustvo. Ovaj se koncept pritom može razmatrati kao jedinstveni fenomen koji varira u intenzitetu (bez obzira na uzorke i okolnosti) te kao multidimenzionalan konstrukt koji razlikuje tipove usamljenosti nastale kao posljedica određenih deficita u odnosima. Weissova tipologija usamljenosti (1979, prema Lacković-Grgin, 2008) oslanja se na multidimenzionalnu konceptualizaciju usamljenosti te razlikuje emocionalnu usamljenost (rezultira iz nedostatka bliskosti u značajnim odnosima) i socijalnu usamljenost (posljedica neuključenosti u socijalnu mrežu). Aspekti usamljenosti kao sastavnice doživljaja socijalne okoline, koji na neki način daju indirektnu informaciju o zadovoljstvu bliskim odnosima i kontaktima s drugima u svojoj okolini, mogli bi igrati važnu ulogu ne samo u procesu ostvarivanja bliskosti u odnosu s kućnim ljubimcem već i kad je riječ o pretpostavljenim ishodnim implikacijama tog odnosa za dobrobit. Mehanizmi takvih relacija vjerojatno su vezani (između ostalog) uz percepciju uloge kućnih ljubimaca, prvenstveno uloge ljubimaca kao socijalnih figura koje su prisutne u svakodnevici čovjeka jednako kao i bliske osobe.

$\mathrm{Na}$ socijalnu funkciju kućnih ljubimaca posve slučajno pozornost je skrenula studija Wood, Giles-Corti, Bulsara i Boscha (2007) čiji je cilj bio kvalitativnom metodom ispitati što sve uvjetuje osjećaj zajedništva u susjedstvu kao užoj socijalnoj sredini. Ukupno 86 sudionika sudjelovalo je u 12 fokusnih grupa koje su raspravljale o viđenju i iskustvima zajedništva te povjerenju i angažmanu unutar malih socijalnih sredina definiranih kao "susjedstva". Ljubimci su se neočekivano istaknuli kao relevantna tema diskusija. Šetnje sa psima povezale su se s većom vjerojatnošću (u)poznavanja lokalnog stanovništva, kod vlasnika ljubimaca kao i kod sudionika koji nisu imali ljubimce. Izgleda da situacija susreta s osobom koja šeta sa svojim psom povećava vjerojatnost „slučajnog“ razgovora, ali i dobro uhodanih razgovora među vlasnicima ljubimaca koji se ponavljaju na dnevnoj bazi. Ljubimci su istaknuti i kao katalizatori socijalnog reciprociteta koji se smatra jednim od proksimalnih markera socijalnog kapitala relevantnog za osjećaj zajedništva. Usluge čuvanja i hranjenja ljubimaca među susjedima povećavaju tako vjerojatnost budućih kontakata, zbližavanja i protuusluga. Posve logično, kućni ljubimci navode se i kao faktor protuteže osjećaju usamljenosti. U recentnijoj studiji Wood i suradnika (2015) naglasak je bio na ispitivanju indirektne uloge za koju je pretpostavljeno da ljubimci imaju prilikom uspostavljanja i razvoja socijalnih kontakata (upoznavanje 
ljudi, formiranje prijateljstava i socijalna podrška). Iako postoje anegdotalni primjeri i kvalitativna istraživanja na ovu temu, funkcija kućnih ljubimaca kao socijalnih lubrikanata rijetko je empirijski istraživana. Uglavnom zaključci sugeriraju kako psi razbijaju led pri tim svakodnevnim kontaktima s drugim ljudima jer posluže kao okidač za razgovor među neznancima (vlasnik i slučajni prolaznici) (npr. Robins, Sanders i Cahill, 1991; Rogers, Hart i Boltz, 1993). Metoda prikupljanja podataka kod Wood i suradnika odnosila se na telefonski intervju, uzorak su činila 2692 sudionika iz Australije i SAD-a. Vlasnici kućnih ljubimaca poznavali su više ljudi $\mathrm{u}$ okviru vlastitog susjedstva u odnosu na sudionike koji nisu imali ljubimca. Za vlasnike pasa iz SAD-a bilo je vjerojatnije da će one ljude koje su upoznali preko ljubimca smatrati prijateljima, u odnosu na vlasnike drugih vrsta kućnih ljubimaca. Oko 40\% vlasnika kućnih ljubimaca izjavilo je da neki od oblika socijalne podrške (emocionalna, informacijska, instrumentalna) pronalaze upravo u ljudima koje su upoznali preko svog ljubimca. Autori zaključuju kako posjedovanje kućnih ljubimaca može biti olakotna okolnost pri socijalnoj interakciji i formiranju prijateljstava unutar susjedstva, odnosno u užoj socijalnoj okolini. Relacija privrženosti ljubim$\mathrm{cu}$, operacionalizirane kao bliska afektivna povezanost, i socijalne podrške od strane drugih ljudi potvrđena je u istraživanju koje je na uzorku od 390 vlasnika pasa kod nas provela Kalinić (2016). Autorica navodi kako je viša afektivna vezanost za ljubimca povezana s većim stupnjem percipirane socijalne podrške od ljudi, što pojašnjava upravo pretpostavkom da privrženiji vlasnici pasa moguće više vremena provode u šetnjama sa svojim ljubimcima koje općenito pružaju priliku za pozitivne socijalne interakcije.

Očito je zasad kako se socijalne dobiti od društva kućnih ljubimaca za ljude koji ih imaju, mogu u najmanju ruku povezati sa katalizirajućom funkcijom koju imaju u kontekstu ostvarivanja, a potom i produbljivanja socijalnih odnosa. Kada je riječ o mogućim mehanizmima putem kojih ljubimci ublažavaju posljedice usamljenosti i depresije, u prvom redu valja uzeti u obzir funkciju koju ljubimci imaju unutar obitelji kao jedan od izvora socijalne podrške (Albert i Bulcroft, 1988; Bonas i sur., 2000; Philips Cohen, 2002; Beck i Katcher, 2003) uz dobro potvrđene nalaze o odnosu socijalne podrške i mentalnog zdravlja kojima literatura obiluje. Korak dalje otišla su istraživanja koja su pokušala kontrolirati (iako je riječ o korelacijskim studijama) interpersonalnu dimenziju odnosa, odnosno promatrati relacije kvalitete odnosa s kućnim ljubimcem i određenih indikatora dobrobiti uzevši u obzir postojeću kvalitetu odnosa sa značajnim bliskim osobama. McConnell, Brown, Shoda, Stayton i Martin (2011) tako su krenuli u provjeru tzv. komplementarne hipoteze prema kojoj se odnos s ljubimcem uklapa u kvalitetu postojećih interpersonalnih odnosa i neovisno doprinosi dobrobiti, i tzv. hidraulične hipoteze prema kojoj će odnos s ljubimcem i njegovi efekti za dobrobit ovisiti o kvaliteti odnosa sa značajnim drugima. Prema prvom stajalištu aspekti kvalitete odnosa s ljubimcem trebali bi samostalno prognozirati varijable dobrobiti, dok bi se prema drugom stajalištu ra- 
dilo o interakciji aspekata odnosa s ljubimcem i aspekata odnosa s bliskim osobama prilikom predviđanja nekih ishodnih varijabli dobrobiti. Drugim riječima, komplementarna hipoteza predviđa samostalan pozitivan efekt bliskog odnosa s ljubimcem na dobrobit (kao što to vrijedi i za bilo koji drugi bliski odnos), dok hidraulična hipoteza pretpostavlja pozitivne efekte ljubimaca u slučajevima kad su odnosi sa značajnim drugima manje kvalitetni (ljubimac kompenzira loše interpersonalne odnose). Autori su imali više istraživačkih ciljeva, a prvi se odnosio na usporedbu ljudi koji imaju i onih koji nemaju kućne ljubimce. Utvrđeno je kako su vlasnici ljubimaca u boljoj fizičkoj formi, imaju više samopoštovanje i više su savjesni i ekstravertirani te manje usamljeni, zaokupljeni i plašljivi u bliskim odnosima. Vlasnici kućnih ljubimaca podjednako su važnim procjenjivali bliske odnose sa značajnim drugima kao i ne-vlasnici, dok je procjena relevantnosti odnosa s kućnim ljubimcem pozitivno korelirala s procjenama odnosa s drugim bliskim figurama. Nadalje, procjena ljubimaca kao onih koji uspješno zadovoljavaju vlasnikove socijalne potrebe pokazala se značajnim nezavisnim prediktorom pozitivnih aspekata dobrobiti (povrh bliskih ljudskih figura koji su kao podrška socijalnim potrebama pojedinca također neovisno prognozirali pozitivne ishode). Dakle pozitivne dobiti od društva ljubimaca, neovisno o zadovoljenju socijalnih potreba u bliskim interpersonalnim odnosima, doprinose općoj dobrobiti. Podršku komplementarnoj hipotezi dodatno pruža i pozitivna korelacija procjene zadovoljenja socijalnih potreba u odnosu s ljubimcem i procjene socijalne podrške od strane drugih (ljudi se očito ne oslanjaju više na svoje ljubimce kad je podrška iz okoline manjkava, ili manje onda kad je interpersonalni sustav potpore jak). Autori zaključuju kako vlasnici kućnih ljubimaca (pasa) imaju višu dobrobit kad procjenjuju da ljubimci zadovoljavaju njihove socijalne potrebe, i to neovisno od stupnju interpersonalne podrške. Ljubimci se mogu smatrati nezavisnim izvorom podrške koji paralelno djeluje uz interpersonalni sustav, dakle rezultati ovog istraživanja generalno podupiru komplementarnu hipotezu.

U sklopu istraživanja koje je kod nas provela Ombla (2014) provjeravana je relacija između afektivne vezanosti za ljubimca i životnog zadovoljstva, odnosno fizičkog zdravlja, uz kontrolu mogućih efekata objektivnih i subjektivnih indikatora kvalitete socijalne okoline. Uzorak je činilo 219 vlasnika pasa koji su procijenjeni kao primarni skrbnici svojih ljubimaca. Kao što je ranije spomenuto, neka su dosadašnja istraživanja uputila na osobitosti tzv. pozitivnog efekta ljubimca s obzirom na strukturu i subjektivni doživljaj socijalne okoline vlasnika (npr. Albert i Bulcroft, 1988; Garrity i sur., 1989; Johnson i sur., 1992; Siegel i sur., 1999; Allen i sur., 2001; Turner, 2005; Krause-Parello, 2008). Osim toga, životno zadovoljstvo i fizičko zdravlje u istraživanjima se konzistentno povezuju s kvalitetom socijalne okoline pojedinca (Lacković-Grgin, 2008). U istraživanju od Ombla (2014) objektivnim indikatorima socijalne okoline smatrali su se ljubavni status, roditeljstvo $i$ broj bliskih osoba, dok su se subjektivnim indikatorima socijalne okoline promatrale socijalna i emocionalna usamljenost te procjena podrške od strane prijatelja u 
stresnim trenucima. Afektivna vezanost za ljubimca pokazala se značajnim umjerenim pozitivnim prediktorom životnog zadovoljstva, i to pod uvjetima kada se efekti varijabli socijalne okoline drže pod kontrolom. Čini se da dublje emocionalno investiranje u odnosu s ljubimcem doprinosi općem životnom zadovoljstvu vlasnika pasa, i to neovisno o strukturi i subjektivnom doživljavanju kvalitete socijalne okoline. Ukratko, rezultatima istraživanja koje su proveli McConnell i suradnici (2011), kao i rezultatima istraživanja koje je provela Ombla (2014), utvrđen je nezavisni efekt određenih karakteristika odnosa s kućnim ljubimcem na prognozu nekih varijabli dobrobiti, i to u uvjetima kontrole efekata varijabli socijalne okoline koje dijelom opisuju kvalitetu odnosa sa značajnim bliskim osobama. Ovi nalazi generalno potkrepljuju hipotezu o komplementarnim međurelacijama i efektima odnosâ sa značajnim drugima i odnosa s ljubimcem (v. McConnel i sur., 2011) prema kojoj se blizak odnos s ljubimcem uklapa u kontekst funkcioniranja odnosa unutar najuže interpersonalne domene. Kako ta hipoteza pretpostavlja komplementarno uklapanje odnosa s ljubimcem u postojeću interpersonalnu strukturi, logično je očekivati i određene relacije s mjerama dobrobiti, ovisno o kvaliteti realiziranih odnosa. U kontekstu provjere karakteristika odnosa s kućnim ljubimcem, važno je još jednom ponoviti kako se čini da taj isti odnos jedinstveno doprinosi psihičkoj dobrobiti pojedinca, povrh efekata kvalitete najuže socijalne okoline. Eksperimentalne studije u ovom području nadalje izoliraju jedinstvene efekte društva kućnih ljubimaca na aspekte dobrobiti. Tako Epley, Akalis, Waytz i Cacioppo (2008) eksperimentalnim putem induciraju osjećaj usamljenosti. Autori navode kako su u takvim uvjetima ljudi skloniji antropomorfizirati svoje ljubimce u smislu da im pripisuju obazrivost i suosjećajnost, što im trenutno pomaže u suočavanju s osjećajem socijalne nepovezanosti. Više studija potvrdilo je blagotvorne fiziološke efekte blizine kućnih ljubimaca na kardiovaskularne varijable u uvjetima induciranog stresa (Allen, 2003; Allen, Blascovich i Mendes, 2002; Allen i sur., 2001). Izgleda da društvo ljubimca pomaže i pri suočavanju s negativnim osjećajima kad percipiramo manjak ljudskih socijalnih resursa, u svakom slučaju blizina životinje čini se funkcionira po principu nezavisne i funkcionalne socijalne zalihe.

Ombla i Vidaković (2016) pokušale su provjeriti hipoteze o komplementarnoj, odnosno mogućoj supstituirajućoj funkciji kućnih ljubimaca krenuvši od racionale da je interpersonalni kontekst u okviru kojeg se razvija odnos s ljubimcem faktor relevantan za razvoj privrženosti u tom odnosu. Individualne odrednice realizacije privrženosti u bliskim odnosima (anksioznost i izbjegavanje) nasuprot usamljenosti u bliskim odnosima kao stanju koje je determinirano tim odrednicama u teoriji se tumače kao indikatori kvalitete bliskih odnosa (Larose, Guay i Boivin, 2002) Dvije skupine vlasnika pasa $(\mathrm{N} 1=219 ; \mathrm{N} 2=67)$, među kojima su postojale značajne razlike u privrženosti u bliskim odnosima i usamljenosti, razlikovale su se i u privrženosti kućnom ljubimcu. Skupina vlasnika pasa koji su lošije funkcionirali na interpersonalnom planu (manja privrženost u bliskim odnosima, veća emocionalna 
i socijalna usamljenost), bila je privrženija svom ljubimcu. Iz svega navedenog, čini se opravdanim ne-generalizirati vlasnike kućnih ljubimaca kao one koji uspješnije (ili manje uspješno) funkcioniraju na interpersonalnom planu, dok upravo odrednice kvalitete bliskih odnosa, čini se, igraju ulogu u razvoju privrženosti u odnosu vlasnik-kućni ljubimac.

Zbog iznimno malog broja studija vođenih kvalitativnom metodologijom u ovom području, ovdje se čini relevantnim spomenuti i istraživanje koje je proveo Blouin (2009) s ciljem ispitivanja stavova vlasnika pasa prema njihovim ljubimcima i životinjama općenito. Autor je proveo 28 dubinskih intervjua s vlasnicima pasa te uočio kako ljubimci igraju važnu ulogu u životima ljudi, osiguravajući im zabavu i društvo koje procjenjuju značajnim, međutim isto tako izvještava kako postoje određene bitne razlike među vlasnicima ljubimaca koje primarno reflektiraju razlike u stavovima prema ljubimcima i životinjama općenito. Blouin definira tri "kategorije" vlasnika ljubimaca, ovisno o vrijednosnoj orijentaciji i stavovima prema ljubimcima i životinjama kojima su naklonjeni: "vlasnici" (dominionists), "humanisti" (humanists) i "zaštitnici" (protectionists). "Vlasnici"1 najmanje cijene društvo svojih ljubimaca, vrednuju ih isključivo prema svrsi i onome što od njih dobivaju, kao što je zaštita na primjer. "Humanisti” svojim ljubimcima pridaju status ljudskih surogata te valoriziraju svoje ljubimce primarno prema pozitivnim afektivnim dobitima koje imaju iz bliskih emocionalnih odnosa s njima. "Zaštitnici" izražavaju visoko poštovanje prema ljubimcima, ali i prema životinjama općenito, te percipiraju svoje ljubimce kao dragocjeno društvo i kao bića koja imaju svoja vlastita prava koja treba poštovati. Blouin pretpostavlja kako su ove različite vrijednosne orijentacije prema životinjama produkt višestrukih utjecaja kulturalnih faktora kao i osobnih iskustava, demografskih karakteristika te obiteljskih utjecaja. U Tablici 1 sažeto su prikazane razlike u karakteristikama triju skupina vlasnika pasa prema Blouinu, koje jasno ilustriraju moguće uzroke kontradiktornih rezultata u ovom području, i kada je riječ o opisivanju karakteristika odnosa vlasnik-kućni ljubimac, i kada je riječ o ishodnim implikacijama tog odnosa za čovjekovu dobrobit. Ovakve nalaze, poput Blouinovih (2009) te onih od Ombla i Vidaković (2016), koji upućuju na određene faktore razlikovanja unutar populacije vlasnika kućnih ljubimaca svakako valja uzimati u obzir prilikom interpretacije rezultata istraživanja budući da se može raditi o faktoru relevantnom za generalizaciju zaključaka, bilo da je riječ o opisivanja samih vlasnika kućnih ljubimaca ili odnosa između ljudi i njihovih kućnih ljubimaca.

1 Napomena: termin "vlasnici" se kod Blouina odnosi na slobodan konotativni prijevod engleskog izraza dominionists i po značenju se razlikuje od termina vlasnici kućnih ljubimaca koji se u tekstu ovog preglednog rada odnosi na sve ljude koji imaju kućnog ljubimca. 
SUVREMENA PSIHOLOGIJA 19 (2016), 2, 217-233

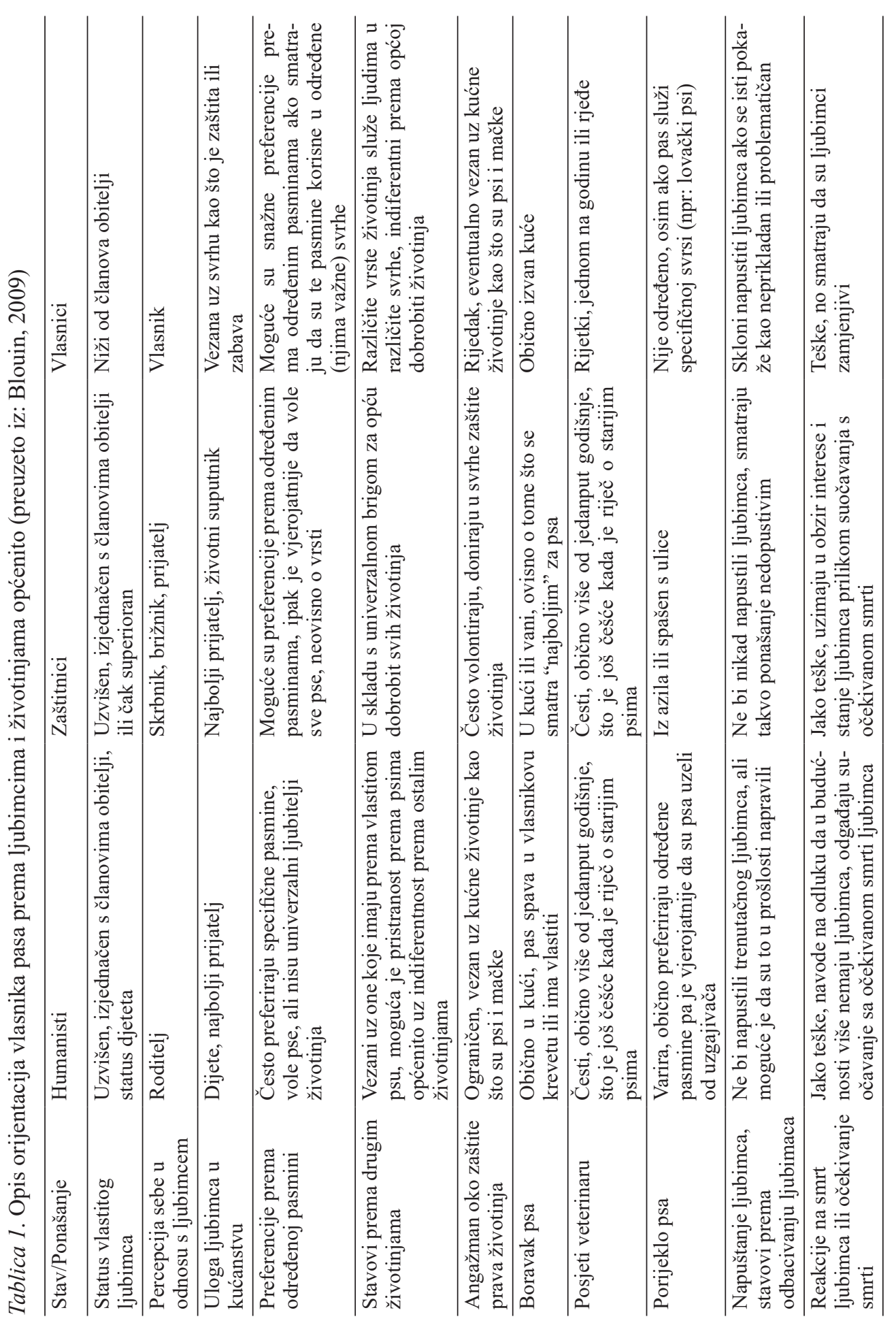




\section{ZAKLJUČAK}

Odnos između vlasnika i njegova kućnog ljubimca u dosadašnjim istraživanjima ove tematike karakterizirao se kao privrženost - $\mathrm{i}$ to primarno temeljem podataka na mjerama afektivne vezanosti s ljubimcima koje nisu operacionalizirale privrženost u punom smislu riječi. Iako je ona nedvojbeno prepoznata kao temelj koji bi valjalo uzeti u obzir pri pokušajima razumijevanja veza koje se formiraju između ljudi i njihovih kućnih ljubimaca, mjere i koncepti koji se baziraju na teoriji privrženosti tek se u posljednje vrijeme počinju primjenjivati u ovom području. U literaturi se navodi kako je istinskoj privrženosti potreban period od otprilike dvije godine da se razvije, i to postupnim javljanjem karakteristika koje razlikuju veze privrženosti od afilijativnih odnosa (traženje blizine, separacijska uznemirenost, sigurno utočište) te konačnom percepcijom figure privrženosti kao sigurne baze $\mathrm{u}$ stresnim trenucima (Hazan i Zeifman, 1999; Fraley i Shaver, 2000; Simpson, Rholes, Campbell i Wilson, 2003). Dakle, izuzevši kompleksnost fenomena privrženosti, i sama razvojna perspektiva predstavlja faktor relevantan za tumačenje privrženih karakteristika nekog odnosa. Uz izuzetak longitudinalnih studija, trenutačna sugestija vezana uz provjeru privrženih karakteristika odnosa vlasnik-kućni ljubimac bila bi usmjerena na provjeru metodološki valjano operacionaliziranih konstrukata privrženosti u ovom odnosu (funkcije privrženosti, dimenzije privrženosti). Pritom se relevantnom čini kvaliteta postojeće bliske interpersonalne okoline u koju se odnos s kućnim ljubimcem uklapa. Čini se kako odnos s kućnim ljubimcem, poglavito kada je riječ o psima, predstavlja funkcionalan i koristan resurs za čovjeka, gotovo poput zasebne socijalne zalihe. Mehanizmi putem kojih postojanje takve dijeljene životne svakodnevice sa životinjom djeluje na čovjeka, na njegovo emocionalno vezivanje za ljubimca i na njegovo opće funkcioniranje, za sada su još uvijek prilično nejasni. Izgleda da bi i neke osobne karakteristike vlasnika ljubimaca, od socioemocionalnih aspekata funkcioniranja pa do stavova i vrijednosnih orijentacija, mogle igrati važnu ulogu u definiranju kvalitete, a potom i ishodnih implikacija ovog odnosa.

\section{LITERATURA}

Albert, A. i Bulcroft, K. (1988). Pets, families and the life course. Journal of Marriage and the Family, 50, 543-552.

Allen, K. (2003). Are pets a healthy pleasure? The influence of pets on blood pressure. $\mathrm{Cu}$ rrent directions in psychological science, 12 (6), 236-239.

Allen, K. (2003). Are pets a healthy pleasure? The influence of pets on blood pressure. $\mathrm{Cu}$ rrent directions in psychological science, 12 (6), 236-239.

Allen, K., Blascovich, J. i Mendes, W.B. (2002). Cardiovascular reactivity and the presence of pets, friends, and spouses: The truth about cats and dogs. Psychosomatic Medicine, 64, 727-739. 
Allen, K., Shykoff, B.E. i Izzo, J.L. (2001). Pet ownership, but not ACE inhibitor therapy, blunts home blood pressure responses to mental stress. Hypertension, 38, 815-820.

Archer, J. i Winchester, G. (1994). Bereavement following death of a pet. British Journal of Psychology, 85, 259-271.

Baston, S. (2009). Pets and the „,need to nurture“. The Future of Human Reproduction: Working Paper 3. St. John'sCollege, Oxford \&Vienna Institute of Demography.

Beck, A.M. i Katcher, A.K. (2003). Future directions in human-animal bond research. American Behavioral Scientist, 47, 79-89.

Beck, L. i Madresh, E.A. (2008). Romantic partners and four-legged friends: An extension of attachment theory to relationships with pets. Anthrozoös, 21 (1), 43-56.

Bell, D.C. i Richard, A.J. (2000). Caregiving: The forgotten element in attachment. Psychological Inquiry, 11 (2), 69-83.

Blouin, D. D. (2009). Are dogs children, companions, or just animals? Understanding variations in people's orientations toward pets. American Sociological Association Annual Meeting, Hilton San Francisco, San Francisco, CA . Preuzeto sa: http://citation.allacademic.com/meta/p307350_index.html

Bonas, S., McNicholas, J. i Collins, G.M. (2000). Pets in the network of family relationships: An empirical study. U: A .L. Podberscek, E. S. Paul i J.A. Serpell (Ur.), Companion animals and us, (209-236). Cambridge: Cambridge University Press.

Bowlby, J. (1969). Attachment and loss. Vol. 1, Attachment. New York: Basic Books.

Brown, S. i Katcher, A.H. (2001.) Pet attachment and dissociation. Society \& Animals, 9 (1), 25-38.

Cain, A.O. (1985). Pets as family members. Marriage \& Family Review. 8 (3), 5-10.

Cassidy, J. (1999). The nature of a child's ties. U: J. Cassidy i P.R. Shaver (Ur.), Handbook of attachment: Theory, research, and clinical applications, (3-20). New York: The Guilford Press.

Cowles, K.V. (1985). The death of a pet: Human responses to the breaking of the bond. Marriage \& Famil yReview, 8 (3), 135-148.

Crawford, E.K., Worsham, N.L. i Swinehart, E.R. (2006.) Benefits derived from companio nanimals, and the use of the term ,attachment“. Anthrozoös, 19 (2), 98-112.

Epley, N., Akalis, S., Waytz, A. i Cacioppo, J.T. (2008). Creating social connection trough inferential reproduction. Psychological Science, 19. 114-120.

Fraley, R.C. i Shaver, P. (2000). Adult romantic attachment: Theoretical developments, emerging controversis, and unanswered questions. Review of General Psychology, 4 (2), $132-154$.

Fraley, R.C. i Shaver, P. (2000). Adult romantic attachment: Theoretical developments, emerging controversis, and unanswered questions. Review of General Psychology, 4 (2), $132-154$.

Garrity, T.F., Stallones, L., Marx, M.B. i Johnson, T.P. (1989). Pet ownership and attachment as suportive factors in the health of the eldery. Anthrozoös, 3 (7), 35-44.

Gunter, B. (1999). Pets and people: The psychology of pet ownership. London: Whurr Publishers Ltd. 
Hart, L.A. (1995). Dogs as human companions: A review of the relationship. U: J. Serpell (Ur.) The domestic dog: its evolution, behavior and interactions with people, (162-178). Cambridge University Press.

Hazan, C. i Zeifman, D. (1999). Pair bonds as attachments. U: J. Cassidy i P.R. Shaver (Ur.), Handbook of attachment: Theory, research and clinical applications, (336-354). New York: The Guilford Press.

Johnson, T.P., Garrity, T.F. i Stallones, L. (1992). Psychometric evaluation of the Lexington Attachment to Pets Scale (LAPS). Anthrozoös, 5 (3), 160-175.

Kalinić, A. (2016). Odnos privrženosti psu i antropomorfizma vlasnika s percepcijom socijalne podrške i depresivnošću. Diplomski rad: Sveučilište u Zadru, Odjel za psihologiju.

Krause-Parello, C.A. (2008). The mediating effect of pet attachment support between loneliness and general health in older females living in the community. Journal of Community Health Nursing, 25, 1-14.

Kurdek, L.A. (2008). Pet dogs as attachment figures. Journal of Social and Personal Relationships, 25 (2), 247-266.

Kurdek, L.A. (2009). Pet dogs as attachment figures for adult owners. Journal of Family Psycholog,, 23 (4), 439-446.

Lacković-Grgin, K. (2008). Usamljenost: Fenomenologija, teorije i istraživanja. Jastrebarsko. Naklada Slap.

Larose, S., Guay, F. i Boivin, M. (2002). Attachment, social support, and loneliness in young adulthood: A test of two models. Personality and Social Psychology Bulletin, 28 (5), 684-693.

McConnell, A.R., Brown, C.M., Shoda, T.M., Stayton, L.E. i Martin, C.E. (2011). Friends with benefits: On the positive consequences of pet ownership. Journal of Personality and Social Psychology, 101 (6). 1239-1252.

Miklósi, A. (2007). Dog behaviour. evolution, and cognition. Oxford University Press.

Mikulincer, M. i Shaver, P.R. (2007). Attachment in adulthood: structure, dynamics and change. The Guilford Press. New York.

Millott, J.L. (1994). Olfactory and visual cues in the interaction systems between dogs and children. Behavioural Processes, 33, 177-188.

Mitchell, R.W. (2001). Americans' talk to dogs: Similarities and differences with talk to infants. Research on Language and Social Interaction, 34 (2), 183-210.

Ombla, J. (2012). Kućni ljubimci i implikacije za zdravlje i psihofizičku dobrobit njihovih vlasnika. Klinička psihologija, 5 (1-2). 59-79.

Ombla, J. (2014). Provjera teorije privrženosti na odnosu vlasnika prema kućnim ljubimcima. Doktorska disertacija. Filozofski fakultet, Sveučilište u Zagrebu.

Ombla, J. i Vidaković, M. (2016). Kvaliteta bliskih odnosa kod vlasnika pasa i aspekti privrženosti kućnom ljubimcu. Rad prihvaćen za objavljivanje. Suvremena psihologija.

Parslow, R.A., Jorm, A.F., Christensen, H., Rodgers, B. i Jacomb, P. (2005). Pet ownership and health in older adults : Findings from a survey of 2551 community - based Australians aged $60-64$.Geruntology, 51, $40-41$.

Philips Cohen, S. (2002). Can pets function as family members? Western Journal of Nursing Research, 24, 621-638. 
Prato-Previde, E., Fallani, G. i Valsecchi, P. (2006.) Gender differences in owners interacting with pet dogs: An observational study. Ethology, 112, 64-73.

Rew, L. (2000). Friends and pets as companions: Strategies for coping with loneliness among homeless youth. Journal of Child and Adolescent Psychiatric Nursing, 13 (3), 125-140.

Robins, D., Sanders, C. i Cahill, S. (1991). Dogs and their people: pet-facillitated interaction in a public setting. Journal of Contemporary Ethnography, 20. 3-25.

Robinson, I. (1992). Pets, and people. U: C. Thorne (Ur.). The Waltham book of dog and cat behaviour. 131-142. Pergamon Press. Oxford.

Rogers, J., Hart, L.A. i Boltz, R.P. (1993). The role of pet dogs in casual conversations of elderly adults. The Journal of Social Psychology, 133. 265-277.

Sable, P. (1995). Pets, attachment, and well-being across the life cycle. Social Work, 40 (3), 334-341.

Serpell, J. A.(1996). In the company of animals: a study of human-animal relationships. Canto. (preuzeto sa: www.books.google.hr)

Shaver, P.R. i Mikulincer, M. (2010). New directions in attachment theory and research. Journal of Social and Personal Relationships, 27 (2), 163-172.

Siegel, J. M. (1990). Stressful life events and use of physician services among the elderly. Journal of Personality and Social Psychology, 58, 1081-1086.

Siegel, J.M., Angulo, F.J., Detels, R., Wesch, J. i Mullen, A. (1999). AIDS diagnosis and depression in the Multicenter AIDS Cohort Study: the ameliorating impact of pet ownership. AIDS Care, 11 (2), 157-170.

Sife, W. (2005). The loss of a pet: A guide to coping with the grieving process when a pet dies. John Wiley \& Sons. New Jersey, SAD.

Simpson, J.A., Rholes, W.S., Campbell, L. i Wilson, C.L. (2003). Change in attachment orientations across the transition to parenthood. Journal of Experimental Social Psychology, 39, 317-331.

Smith S. L. (1983). Interactions between pet dog and family members: An ethological study. U: A. Katcher i A. Beck (Ur.) New perspectives on our lives with companion animals. (str. 29-36) University of Pennsylvania Press.

Stanley, I.H., Conwell, Y., Bowen, C., Van Orden, K. (2014). Pet ownership may attenuate loneliness among older adult primary care patients who live alone. Aging \& Mental Health, 18 (3). 394-399.

Turner, W. (2005). The role of companion animals troughout the family life cycle. Journal of Family Social Work, 9 (4), 11-21.

Wood, L., Martin, K., Christian, H., Nathan, A., Lauritsen, C., Houghton, S., Kawachi, I. i McCune, S. (2015). The pet factor- Companion animals as a conduit for getting to know people, friendship formation and social support. Plos One, 1-17.

Wood, L.J., Giles-Corti, B., Bulsara, M.K. i Bosch, D.A. (2007). More than a furry companion: The ripple effect of companion animals on neighborhood interactions and sense of community. Society and Animals, 15. 43-56.

Dodatni izvori:

Izvještaj (2009). Zaštita životinja u RH i percepcija udruga za zaštitu životinja. FuturaUdruga za zaštitu životinja. 


\author{
www.humanesociety.org \\ www.dogsnews.co.uk \\ www.petnet.com.au \\ www.askgfk.hr \\ http://www.avma.org/issues/human_animal_bond.asp
}

\title{
SOCIOEMOTIONAL CONTEXT OF ATTACHMENT TO PETS
}

\begin{abstract}
Summary
Pets are a global phenomenon and represent an inevitable part of everyday life for more than half of the human population. The purpose of pet ownership isn't explicitly defined, the exact role of pet owner isn't socially expected, and that makes this research area scientifically intriguing. Research shows that people highly value their pets, especially when it comes to pet dogs, considering them as family members and connecting with them in close affectional bonds. Taking care of pet dogs represents a functional and useful resource for humans, almost as a separate social provision. Lately, research on the characteristics of human-pet animal companionship has focused on exploring the elements of attachment in this relationship. Determinants of quality of close relations seem to have an important role in the development of attachment to pets, while action mechanisms on human well-being need to be explored further. Generally, it seems like some personal characteristics of pet owners, from socioemotional functioning to attitudes and value orientations, could be relevant in defining the quality as well as the outcome implications of human-animal companionship.
\end{abstract}

Key words: pets, socioemotional context, attachment 
